\title{
MEGAGAUSS MAGNETIC FIELD GENERATION, ITS APPLICATION TO SCIENCE AND ULTRA-HIGH PULSED-POWER TECHNOLOGY
}


This page intentionally left blank 


\title{
MEGAGAUSS MAGNETIC FIELD GENERATION, ITS APPLICATION TO SCIENCE AND ULTRA-HIGH PULSED-POWER TECHNOLOGY
}

\author{
Proceedings of the \\ VIIIth International \\ Conference on Megagauss \\ Magnetic Field Generation \\ and Related Topics
}

Tallahassee, Florida, USA

18-23 October 1998

Edited by

Hans J. Schneider-Muntau

National High Magnetic Field Laboratory

Florida State University, USA 


\section{Published by}

World Scientific Publishing Co. Pte. Ltd.

5 Toh Tuck Link, Singapore 596224

USA office: 27 Warren Street, Suite 401-402, Hackensack, NJ 07601

UK office: 57 Shelton Street, Covent Garden, London WC2H 9HE

\section{British Library Cataloguing-in-Publication Data}

A catalogue record for this book is available from the British Library.

The editor of this book wishes to thank those who worked so hard to make the conference such a success. A greater challenge turned out to be the peer review of all the articles and the editing of the book. The untiring efforts of Ms. Pam Houmere for the technical editing of the papers are especially recognized. Without her help this book would not have been possible. Many thanks also go to the people who helped over the years with the follow-up on the collection of the original and reviewed papers: Ms. Terry Pace, Janet Neff-Shampine, again Pam Houmere, and others.

The peer review of the papers and the book was produced with ultimate care. Nevertheless, we cannot warrant the information contained in this book to be free of errors. The quality of the pictures, figures, and equations stems from the originals we received from the authors.

Particular thanks go to Mr. Walter Thorner for the design and lay-out of the book.

On the Cover: The National High Magnetic Field Laboratory in Tallahassee, Florida with a reproduction of the $2800 \mathrm{~T}$ ( 28 MGauss) field pulse obtained in Sarov in 1998.

\section{MEGAGAUSS VIII}

Proceedings of the VIII International Conference on Megaguass Magnetic Field Generation and Related Topics

Copyright $\circledast 2004$ by World Scientific Publishing Co. Pte. Ltd.

All rights reserved. This book, or parts thereof, may not be reproduced in any form or by any means, electronic or mechanical, including photocopying, recording or any information storage and retrieval system now known or to be invented, without written permission from the Publisher.

For photocopying of material in this volume, please pay a copying fee through the Copyright Clearance Center, Inc., 222 Rosewood Drive, Danvers, MA 01923, USA. In this case permission to photocopy is not required from the publisher.

ISBN $982-256-016-5$

This book is printed on acid-free paper.

Printed in Singapore by Mainland Press 



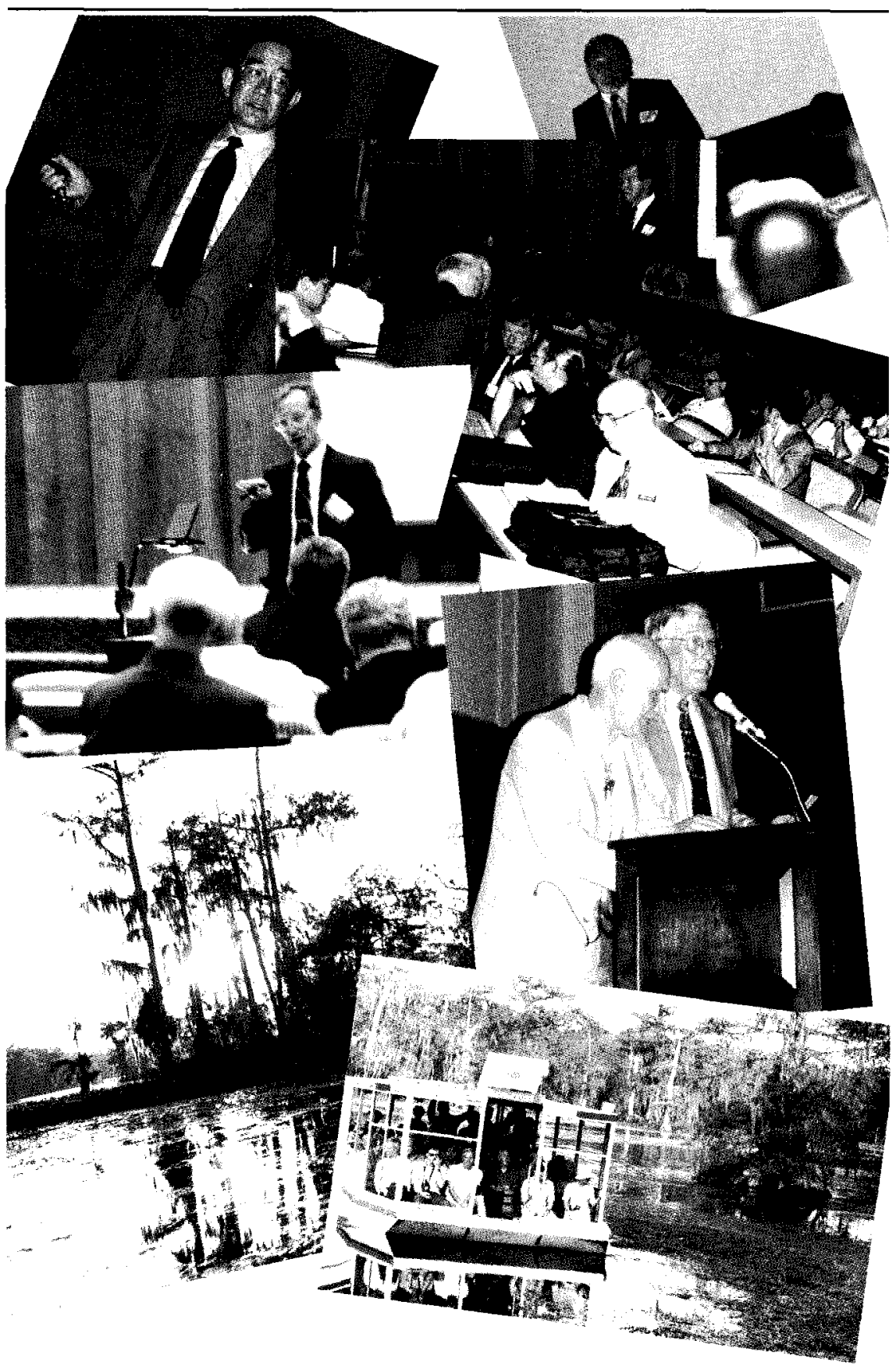

vit Megagauss Magnetic Field Generation, its Application to Science and Ultra-High Pulsed-Power Technology 


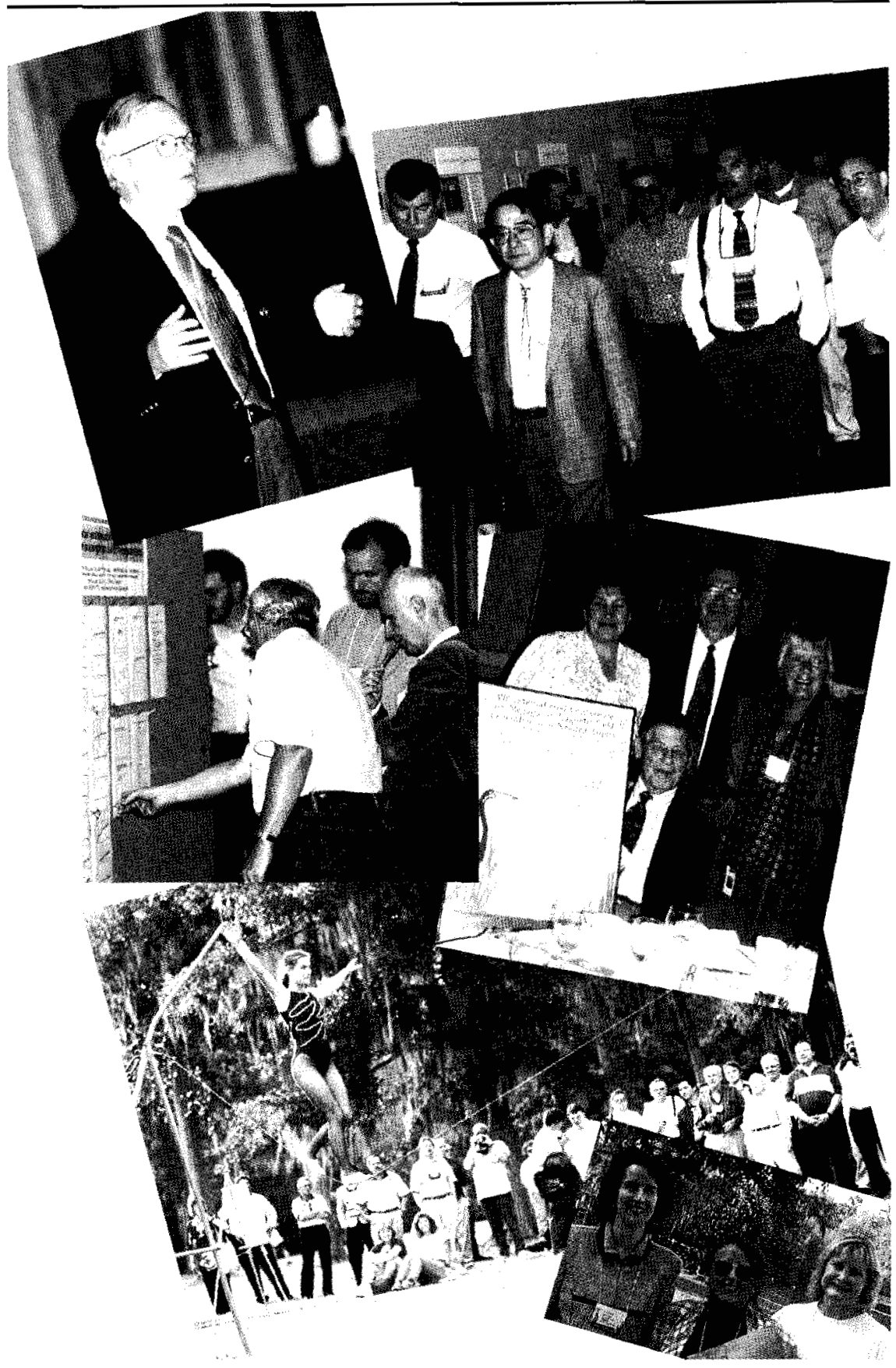

VIIIth INTERNATIONAL CONFERENCE ON MEGAGAUSS MAGNETIC FIELD GENERATION AND RELATED TOPICS • Tallahassee, FL, USA, October 18-23, 1998 
This page intentionally left blank 


\section{DEDICATED TO THE $80^{\text {th }}$. BIRTHDAY OF MAX FOWLER}

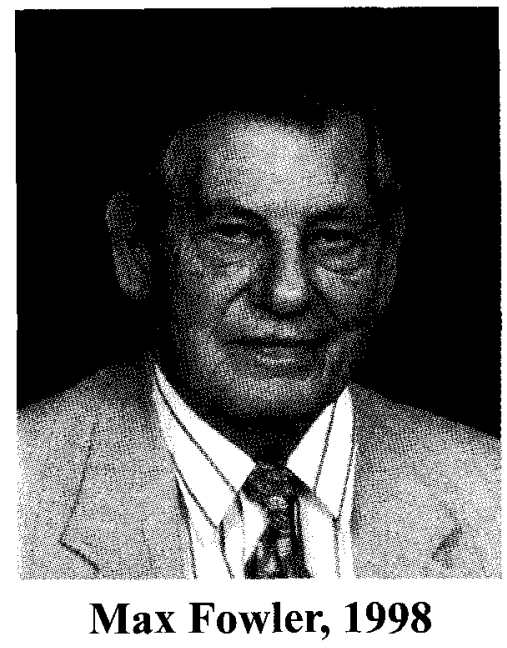

During the "Megagauss VII" Conference in Sarov, the International Steering Committee voted to ask the National High Magnetic Field Laboratory to host the next "MegagaussVIII" Conference in Tallahassee, Florida, U.S.A. and to dedicate it to the $80^{\text {th }}$ birthday of Dr. Clarence M. Fowler, known simply as "Max" to his many friends and colleagues. By this decision, the International Steering Committee emphasized not only the outstanding contribution of Max Fowler as a pioneer in the field of megagauss magnetic field generation, design of generators of magnetic fields and electromagnetic energy, and the application of the generators to various problems of experimental physics, but especially his outstanding contribution to the creation of the International Megagauss Community.

It is a great honor for us to write this short article about Max, our wonderful colleague and friend. To write about Max is simultaneously easy and difficult. There are two attributes which we find remarkable; his outstanding scientific success, because many of his papers became classical and well known to the scientific community, and his scientific drive infecting everyone he met with his enthusiasm and passion for research.

Max Fowler was born in November 26, 1918, in the small town of Centralia, Illinois, U.S.A. He obtained a B.S. degree in Chemical Engineering from the University of Illinois in 1940. After graduation, he worked at the American Steel and Wire Company in Cleveland, Ohio. There, he met his future wife, Janet Brown. Max and Janet will soon celebrate their $60^{\text {th }}$ wedding anniversary. Following the outbreak of WWII, he enlisted in the Navy. Upon his discharge in mid 1946, he enrolled as a graduate student in Physics at the University of Michigan. After completing his graduate work in late 1949, Max accepted an appointment at Kansas State University (KSU) as Assistant Professor. He set up a laboratory at KSU dedicated mainly to the beta and gamma ray spectroscopy of neutron induced radioactive rare-earth elements. In the early 1950's, he started at the Los Alamos Scientific Laboratory as a summer Visiting Scientist. It was during these visits that Max fired his first flux compression shots. He eventually resigned from his position as Full Professor of Physics at KSU in 1957 to devote all of his time to a broad program in Magnetic Flux Compression at Los Alamos. 
A pioneer himself, Max is linked to early pioneers such as Peter Kapitza and Francis Bitter. Bitter worked as a consultant during many summers in Los Alamos developing new designs of pulse magnets to increase the seed field of flux compression devices. Max is also connected to another pioneer, Heinz Knoepfel, who developed a flux compression facility with Fritz Herlach in Frascati, Italy.

Dr. Fowler is the author or coauthor of nearly 200 open-literature publications on such different subjects as difference equation stability, diffusion, nuclear spectroscopy, shock wave induced phase transitions and other effects in metals, and most predominantly in explosive flux compression. Over the years, he and his colleagues have utilized explosive flux compression to produce very large magnetic fields and to generate large electromagnetic pulses. They have used both techniques in many applications, including megagauss field generators for solid state research, pulsed power supplies for a number of devices including theta pinches, plasma guns, plasma focuses, lasers, imploding foils for soft X-ray production, e-beam accelerators, rail guns and, more recently, as magnetic field generators to study hightemperature superconductors in megagauss fields.

We mention here explicitly three of Max's especially worthy publications. His very first paper was titled "Analysis of Numerical Solutions of Transient Heat Flow Problems" [1]. Max is very proud of this paper. He told us that he has received the most reprint requests for this paper. His contribution was awarded the Miller Prize in mathematics at the University of Michigan. Max's most significant and well-known paper is the "Production of very high magnetic fields by implosion" [2]. It was the first report of magnetic field generation above $10 \mathrm{MG}$ and up to $14 \mathrm{MG}$. It stimulated much work in liner implosion of plasmas, material research in megagauss fields and ultimately, the Megagauss Conferences. Let us note that it took almost 40 years to double the field value to $28 \mathrm{MG}$ as reported at this conference [3]. As the third paper, we wish to cite the review paper at this conference [4] where Max gives a thorough overview of his work in flux compression.

Max's earlier work had a strong influence on subsequent megagauss-field solid-state research, liner implosion of plasmas, and on the initiation of the International Conferences on Explosive Generation of Megagauss Fields and Related Topics, now known as the Megagauss (MG) Conferences. Dr. Fowler chaired the MG Conference held in Santa $\mathrm{Fe}, \mathrm{NM}$ in 1986 and, as a member of the International Steering Committee, assisted in organizing most of the other Megagauss Conferences. Relations with Russian colleagues, within limitations imposed by the political climate of those times, were greatly stimulated by the relationship that developed between Fowler and Gennady Shvetsov, of the Lavrentyev Institute of Hydrodynamics in Novosibirsk. This collegial relationship then led to one with the late Academician Alexander Pavlovski, who directed a similar flux compression effort at Sarov, a complex similar to Los Alamos and now Los Alamos" "sister city". The existence of the subsequent, unclassified scientific programs carried out jointly between these two "weapons" laboratories, was due in considerable part to the Pavlovski-Fowler relationship. It was their profound friendship and the peaceful scientific cooperation that helped to break the ice between the U.S. and Russia at the end of the cold war. Max was also instrumental in helping the Florida State University/University of Florida/Los Alamos Proposal to develop the National High Magnetic Field Laboratory partly due to the high magnetic field research done at Los Alamos by the Explosive Flux Compression Team.

Dr. Fowler has served on a number of panels and committees including the National Science Foundation Panel on High Magnetic Fields, the Defense Science Board, NATO, DOE, DoD, and has directed a number of programs for some of these organizations. He 
is a long-time Fellow of the American Physical Society (1964) and was one of the early Los Alamos National Laboratory Fellow Appointees (1982). Dr. Fowler was awarded an Honorary Doctorate from Novosibirsk State University for his work in high energy density physics and for furthering scientific relations between the United States and Russia. He was honored in a special session of the MG VIII Conference held in Tallahassee in 1998. Although retired for several years, he has remained active in both publishing and lecturing. In the last two years, besides lectures in the U.S., he has presented lecture series in Korea, Russia and Germany.

At the special session of the MG-VIII Conference at which friends and colleagues congratulated Dr. Max Fowler on his anniversary, conference participants of the Lavrtentyev Institute of Hydrodynamics read out the following congratulation:

"Dear Max,

In everyone's life there happen events that can be considered the most important and years later the person realizes better and better how many things in his personal life would be different if this event did not occur. For us, such an event was the acquaintance and cooperation with you. In your person we have an outstanding scientist, a reliable friend, and a wonderful man. Today, many-many years after our first meetings in Los Alamos and Novosibirsk, we thank our lucky stars that we have the good fortune to know and love you and work together with you.

Our hearts are with you and your incomparable Janet. On the occasion of your 80th birthday we wish you good health and great success."

We would like to conclude this dedication by joining in the above wishes from the depth of our hearts.

Gennady A. Shvetsov

Hans J. Schneider-Muntau

\section{References}

1. Fowler, C. M., Analysis of Numerical Solutions of Transient Heat Flow Problems, Quart. Appl. Math. 3 (1946) p. 361.

2. Fowler, C. M., Garn, W. B., Caird, R. S., Production of Very High Magnetic Fields by Implosion, $J$. Appl. Phys. 31 (1960) p. 588. Also, Bull. Am. Phys. Soc., 4 (1959) p. 96.

3. Boyko, B. A., Bykov, A. I., Dolotenko, M. I., Kolokol'chikov, N. P., Markevtsev, I. M., Tatsenko, O. M., Shulvalov, A. M., Generation of Magnetic Fields Above 2000T with the Cascade MagnetoCumulative Generator MC-1, this conference.

4. Fowler, C. M., Explosive Flux Compression: a Review of 50 Years of Los Alamos National Laboratory Activities, this conference. 
This page intentionally left blank 


\section{EDITOR'S PREFACE}

The generation of megagauss fields for science and technology is an exciting area where new physical phenomena, technological challenges, and the selection and development of materials together create a unique potential and synergy resulting in fascinating discoveries and achievements. The controlled handling and applications of extremely high power and energy densities in small volumes and on short time scales is the common theme of this collection of contributions. All papers have been peer-reviewed and carefully edited.

The VIIIth International Conference on Megagauss Magnetic Field Generation and Related Topics (MG-VIII) united more than 200 participants from over 14 countries, with 87 delegates from the U.S. and 30 from Russia. These Proceedings provide the latest research results on the generation of very high magnetic felds up to and well above the megagauss level. One of the highlights is the report on the highest magnetic field ever generated, $2800 \mathrm{~T}$ ( $28 \mathrm{MG}$ ), using explosive flux compression technology. An entire session is devoted to the Dirac series of scientif $c$ experiments in fields up to $1000 \mathrm{~T}$. Contributions about the generation of fields in the millisecond pulse range, $f$ elds in small volumes, and material developments in this area, conclude the $f$ rst section of the Proceedings.

Megagauss VIII was held in connection with the conference "Physical Phenomena at High Magnetic Fields - III" (PPHMF-III) in order to encourage and facilitate cross-links between the two scientif $c$ communities. This was highly successful since 26 PPHMF participants also registered at MG-VIII. The chapter "Science in Megagauss Magnetic Fields" ref ects these contributions.

The following section of the Proceedings is devoted to new results in the more traditional fields of the Megagauss conference: generation of plasmas, magnetized plasma, imploding liners, and fusion. Two major chapters describe progress with generators that use explosives to create ultra-high pulsed power for different applications, and other activities such as rail guns and launchers, codes and modeling. All of these contributions underline the ever-growing importance of advancing ultra-high power density technologies. The Proceedings close with descriptions of magnetic feld facilities that are open to users who wish to do experiments in high and ultra-high magnetic $f$ elds.

The conference organizers want to thank the members of the International Steering Committee, the Program Committee, and the Local Organizing Committee. Help and assistance by the Megagauss Institute Inc. is especially recognized. Our gratitude also goes to the numerous conference sponsors who helped to make the conference become such a congenial and successful meeting.

It is impossible to acknowledge all those who helped to organize the conference. Special thanks go to Ysonde Jensen, Joanne Palmer, and Brenda Cornett. These Proceedings would not have been possible without the guidance of the Board of Editors and the untiring help of Pam Houmere and Walter Thorner. Peer review, editing of the many foreign contributions and putting them into a coherent electronic format turned out to be a major effort.

Hans J. Schneider-Muntau

VIIITh INTERNATIONAL CONFERENCE ON MEGAGAUSS MAGNETIC FIELD GENERATION AND RELATED TOPICS • Tallahassee, FL, USA, October 18-23, 1998 
This page intentionally left blank 


\section{INTERNATIONAL STEERING COMMITTEE}

Larry L. Altgilbers - Missile Defense Space Technology Center

William L. Baker - Phillips Laboratory

Evgenii I. Bichenkov - Lavrentyev Institute of Hydrodynamics/Russian Academy of Sciences

Jay B. Chase - Lawrence Livermore National Laboratory

Maynard (Bill) Cowan - Sandia National Laboratories

Dennis J. Erickson - Los Alamos National Laboratory

C. Max Fowler - Los Alamos National Laboratory

James H. Goforth - Los Alamos National Laboratory

F. Herlach - Catholic University, Leuven

Noboru Miura - Institute for Solid Physics/University of Tokyo

Bob Reinovsky - Los Alamos National Laboratory

Hans J. Schneider-Muntau - National High Magnetic Field Laboratory

Victor D. Selemir - All-Russian Scientif c Research Institute of Experimental

Physics

Gennady A. Shvetsov - Lavrentyev Institute of Hydrodynamics/Russian Academy of Sciences

Vladimir M. Titov - Lavrentyev Institute of Hydrodynamics/Russian Academy of Science

Peter J. Turchi - The Ohio State University

E. P. Velikhov - Kurchatov Institute for Atomic Energy

\section{PROGRAM COMMITTEE}

L. Campbell - Los Alamos National Laboratory

R. Clark - University of New South Wales

J. Degnan - Air Force Research Laboratory, Phillips Reseach Site, Kirtland AFB

P. Frings - Van Der Waals-Zeeman Institute

J. Goforth - Los Alamos National Laboratory

F. Herlach - Catholic University, Leuven

$\mathrm{H}$. Jones - University of Oxford

W. Joss - Grenoble High Magnet Field Laboratory

K. Kindo - Osaka University

A. Lagutin - Kurchatov Institute of Atomic Energy

N. Miura - Institute for Solid State Physics

N. Popkov - Russian Federal Nuclear Center, All-Russian Scientif c Research Institute of Experimential Physics

R. Reinovsky - Los Alamos National Laboratory

G.A. Shneerson - St. Petersburg Technical University

G. Shvetsov - Lavrentyev Institute of Hydrodynamics

R. Spielman - Sandia National Laboratories

M. Springford - H.H. Wills Physics Laboratory, University of Bristol

P. Turchi - The Ohio State University

M. von Ortenberg - Humboldt University, Berlin 


\section{LOCAL ORGANIZING COMMITTEE}

Jim Brooks - National High Magnetic Field Laboratory Jack E. Crow - National High Magnetic Field Laboratory James H. Degnan - Phillips Laboratory Lloyd Engel - National High Magnetic Field Laboratory C. Max Fowler - Los Alamos National Laboratory Jerry T. Jones - Air Force Wright Laboratory Daniel A. Matuska - Orlando Technology, Inc. Bob Reinovsky - Los Alamos National Laboratory Dwight Rickel - Los Alamos National Laboratory Alita Roach - Los Alamos National Laboratory Hans J. Schneider-Muntau - National High Magnetic Field Laboratory Rick B. Spielman - Sandia National Laboratories

\section{SPONSORING ORGANIZATIONS}

Los Alamos National Laboratory

Sandia National Laboratories

Air Force Research Laboratory, Phillips Site, Kirtland AFB

National High Magnetic Field Laboratory

Megagauss Institute

Russian Federal Nuclear Center, All-Russian Scientific Research Institute of Experimental Physics

Oxford Instruments

Keithley Instruments

F.W. Bell, Division of Bell Technologies

GMW Associates

Lakeshore Cryotronics

Janis Research Co.

Leon County Tourist Development Council 


\section{TABLE OF CONTENTS}

OVERVIEWS AND LECTURES

ADVANCED HIGH EXPLOSIVE PULSED POWER TECHNOLOGY AT VNIIEF

V. K. CHERNYSHEV

THE DIRAC EXPERIMENTS - RESULTS AND CHALLENGES

R. G. CLARK, J. L. O'BRIEN, A. S. DZURAK, B. E. KANE, N. E. LUMPKIN,

D. J. REILLEY, R. P. STARRETT, D. G. RICKEL, J. D. GOETTEE, L. J. CAMPBELL,

C. M. FOWLER, C. MIELKE, N. HARRISON, W. D. ZERWEKH, D. CLARK,

B. D. BARTRAM, J. C. KING, D. PARKIN, H. NAKAGXVIIAWA, and N. MIURA

EXPLOSIVE FLUX COMPRESSION: 50 YEARS OF LOS ALAMOS ACTIVITIES

C. FOWLER, D. THOMSON, and W. GARN

A REVIEW OF U. S. HIGH EXPLOSIVE PULSED POWER SYSTEMS

J. H. GOFORTH

MEGAGAUSS FIELDS FROM FORTY YEARS AGO INTO THE

NEXT CENTURY

F. HERLACH

THEORIES OF HIGH TEMPERATURE SUPERCONDUCTIVITY

J. R. SCHRIEFFER

INVESTIGATIONS OF FLUX COMPRESSION ENERGY SOURCES AND

ULTRA-HIGH MAGNETIC FIELD GENERATORS IN VNIIEF

V. D. SELEMIR, and V. A. DEMIDOV

ELECTROMAGNETIC LAUNCH - STATE OF THE ART AND OPPORTUNITIES G. A. SHVETSOV

\section{GENERATION OF MEGAGAUSS MAGNETIC FIELDS}

Ultra - High Magnetic Fields

MORE THAN 20 MG MAGNETIC FIELD GENERATION IN THE CASCADE MAGNETOCUMULATIVE MC- 1 GENERATOR

B. A. BOYKO, A. I. BYKOV, M. I. DOLOTENKO, N. P. KOLOKOL'CHIKOV,

1. M. MARKEVTSEV, O. M. TATSENKO, and A. M. SHUVALOV

ULTRA-HIGH MAGNETIC FIELDS GENERATION USING A DISK

FLUX COMPRESSION GENERATOR OF ENERGY

V. D. SELEMIR, V. A. DEMIDOV, A. A. KARPIKOV, YU. V. VLASOV, S. A. KAZAKOV, and N. P. KOLOKOLCHIKOV

MULTIPLE-TURN MAGNETOCUMULATIVE GENERATOR

A. J. KARTELEV and V. K. CHERNYSHEV

GENERATION OF MEGAGAUSS MAGNETIC FIELDS BY INITIATION AND GROWTH OF MHD INSTABILITIES

P. I. ZUBKOV and K. A. TEN

INVESTIGATION OF EFFECTIVENESS OF MC-1 GENERATOR CASCADES MATERIAL MADE FROM POWDER COMPOSITE

V. V. ASEEVA, B. A. BOYKO, A. I. BYKOV, M. I. DOLOTENKO, N. P. KOLOKOL'CHIKOV,

O. M. TATSENKO, and V. I. TIMAREVA

\section{GENERATION OF MEGAGAUSS MAGNETIC FIELDS}

Non-Destructive High Magnetic Fields/Conductor Development

MEGAGAUSS FIELDS DURING MILLISECONDS

L. J. CAMPBELL, D. EMBURY, K. HAN, D. M. PARKIN, A. G. BACA, K. H. KIHARA,

J. R. SIMS, G. BOEBINGER, Y. EYSSA, B. LESCH, L. LI, J. SCHILLIG,

H. J. SCHNEIDER-MUNTAU, and R. WALSH 
PULSED POWER SUPPLY BASED ON MAGNETIC ENERGY STORAGE

FOR NON-DESTRUCTIVE HIGH FIELD MAGNETS

G. AUBERT, S. DEFOUG, W. JOSS, P. SALA, M. DUBOIS, and V. KUCHINSK

HIGH FIELD PULSED MAGNETS FOR CHARACTERISATION OF

TECHNICAL HIGH TEMPERATURE SUPERCONDUCTORS

P. M. SALEH, D. T. RYAN, and H. JONES

GENERATION OF MEGAGAUSS FIELDS IN INDESTRUCTIBLE

SOLENOIDS WITH QUASI-FORCE-FREE WINDINGS

G. A. SHNEERSON, E. L. AMROMIN, V. Y. KHOZIKOV, and A. I. BOROVKOV

SPATIAL MULTI-TURN STRUCTURE OF FLAT SHEETS FOR MEGAGAUSS MAGNETIC FIELD GENERATION

I. P. EFIMOV, S. I. KRIVOSHEYEV, and G. A. SHNEERSON

OPTIMAL USE OF MAGNETIC ENERGY IN A MAGNET

R. KRATZ, Y. M. EYSSA, L. LI, H. J. SCHNEIDER-MUNTAU, M. R. VAGHAR, and S. W. VAN SCIVER

1-, 2- AND N-COIL SYSTEMS

R. KRATZ, Y. M. EYSSA, L. LI, H. J. SCHNEIDER-MUNTAU, M. R. VAGHAR, and S. W. VAN SCIVER

THE CONSTRUCTION OF HIGH PERFORMANCE PULSE MAGNETS AT NHMFL

B. LESCH, V. COCHRAN, L. LI, P. PERNAMBUCO WISE, S. TOZER,

H. J. SCHNEIDER-MUNTAU, and S: VAN SCIVER

DESIGN OF A 90 T PULSE MAGNET

M. R. VAGHAR, L. LI, Y. EYSSA, H. J. SCHNEIDER-MUNTAU, and R. KRATZ

HIGH FIELD PULSE MAGNETS WITH NEW MATERIALS

L. LI, B. LESCH, V. G. COCHRAN, Y. EYSSA, S. TOZER, C. H. MIELKE,

D. RICKEL, S. W. VAN SCIVER, and H. J. SCHNEIDER-MUNTAU

NEW CONDUCTORS FOR MAGNETS

S. ASKÉNAZY, F. LECOUTURIER, L. THILLY, and G. COFFE

INVESTIGATION, DEVELOPMENT AND MANUFACTURE OF HIGH

STRENGTH, HIGH CONDUCTIVITY CU/SS WIRE FOR LARGE

SCALE MAGNETS

V. PANTSYRNYI, A. SHIKOV, A. NIKULIN, G. VEDERNIKOV, I. GUBKIN, and N. SALUNIN

A SURVEY OF PROCESSING METHODS FOR HIGH

STRENGTH-HIGH CONDUCTIVITY WIRES FOR HIGH

FIELD MAGNET APPLICATIONS

J. D. EMBURY and K. HAN

INTERNAL STRESSES IN WIRES FOR HIGH FIELD MAGNETS

K. HAN, J. D. EMBURY, A. C. LAWSON, R. B. VON DREELE, J. T. WOOD, and J. W. RICHARDSON, JR.

FABRICATION ROUTES FOR HIGH STRENGTH-HIGH CONDUCTIVITY WIRES

J. D. EMBURY, K. HAN, J. R. SIMS, J. Y. COULTER, V. I. PANTSYRNYI, A. SHIKOV, and A. A. BOCHVAR

\section{GENERATION OF MEGAGAUSS MAGNETIC FIELDS \\ High Magnetic Fields in Small Volumes}

GIGAGAUSS MAGNETIC FIELD GENERATION FROM HIGH INTENSITY LASER SOLID INTERACTIONS

J. SEFCIK, M. D. PERRY, B. F. LASINSKI, A. B. LANGDON, T. COWAN,

J. HAMMER, S. HATCHETT, A. HUNT, M. H. KEY, M. MORAN, D. PENNINGTON, R. SNAVELY, J. TREBES, and S. C. WILKS 
ELECTRICAL AND THERMAL PROPERTIES OF

MICROELECTROMAGNETS FOR ATOM MANIPULATION

M. DRNDIC, K. S. JOHNSON, M. PRENTISS, and R. M. WESTERVELT

NONDESTRUCTIVE MINI-COILS APPROACHING

MEGAGAUSS FIELDS

M. VON ORTENBERG and H.-U. MUELLER

MAGNETO-OPTIC MEASUREMENTS UP TO $50 \mathrm{~T}$ USING

MICRO-COILS

K. MACKAY, M. BONFIM, D. GIVORD, A. FONTAINE, and J. C. PEUZIN

FEASIBILITY OF MICRO-COILS

L. LI, H. J. SCHNEIDER-MUNTAU, S. WIRTH, V. NEU, P. XIONG, and S. VON MOLNAR

MICRO-MAGNETS

F. HERLACH, A. VOLODIN, and C. VAN HAESENDONCK

EARLY ATTEMPTS AT MINI (SUPERCONDUCTING)

MAGNETS - ON THE WAY TO MICRO MAGNETS? H. JONES

HIGH TEMPERATURE SUPERCONDUCTING THIN FILM MAGNETS Y. S. HASCICEK, Y. EYSSA, S. W. VAN SCIVER, and H. J. SCHNEIDER-MUNTAU

\section{SCIENCE IN MEGAGAUSS MAGNETIC FIELDS}

PHYSICAL PROCESSES IN DYNAMIC MAGNETIC FIELDS TO $800 \mathrm{~T}$

J. S. BROOKS, J. COTHERN, J. A. SIMMONS, M. J. HAFICH, W. LEWIS,

S. GALLEGOS, D. DEVORE, B. MARSHALL, M. GROVER, G. LEACH,

C. H. MIELKE, D. RICKEL, J. D. GOETTEE, D. CLARK, M. FOWLER, J. KING,

L. TABAKA, J. DETWILER, E. C. CLARK, O. TATSENKO, V. PLATONOV, A. BYKOV,

C. LANDEE, and M. TURNBULL

MAGNETIC SYSTEMS IN MEGAGAUSS MAGNETIC FIELDS;

RESULTS OF DIRAC AND KAPITSA EXPERIMENTS

O. M. TATSENKO and V. D. SELEMIR

OVERVIEW OF THE 1997 DIRAC HIGH-MAGNETIC-FIELD-EXPERIMENT SERIES AT LOS ALAMOS

D. A. CLARK, L. J. CAMPBELL, K. C. FORMAN, C. M. FOWLER,

J. D. GOETTEE, C. H. MIELKE, D. G. RICKEL, and B. R. MARSHALL

QUANTUM TRANSFORMATIONS OF $\mathrm{Fe}_{8}$ MAGNETIC

NANOCLUSTERS IN MEGAGAUSS MAGNETIC FIELDS

A. I. BYKOV, M. I. DOLOTENKO, A. V. FILIPPOV, N. P. KOLOKOL'CHIKOV,

V. V. PLATONOV, O. M. TATSENKO, I. A. LUBASHEVSKY, A. A. MUKHIN,

G. G. MUSAEV, V. I. PLIS, A. I. POPOV, V. D. SELEMIR, and A. K. ZVEZDIN

SPIN-FLIP TRANSITION AND FARADAY EFFECT IN $\mathrm{MnF}_{2}$

IN MEGAGAUSS MAGNETIC FIELD

V. V. PLATONOV, O. M. TATSENKO, D. A. CLARK, C. M. FOWLER,

J. D. GOETTEE, D. G. RICKEL, W. LEWIS, B. MARSHALL, A. A. MUKHIN,

V. I. PLIS, A. I. POPOV, and A. K. ZVEZOIN

NANO-SCALE FERRIMAGNET $\mathrm{Mn}_{12}$ AC IN MEGAGAUSS

MAGNETIC FIELD

V. V. PLATONOV, O. M. TATSENKO, A. I. BYKOV, D. A. CLARK, C. M. FOWLER,

J. D. GOETTEE, D. G. RICKEL, A. K. ZVEZDIN, A. A. MUKHIN,

I. A. LUBASHEVSKY, V. I. PLIS, A. I. POPOV, B. BARBARA, A. CANESCHI,

D. GATTESCHI, and R. SESSOLI

INVESTIGATION OF LEVEL CROSSING EFFECT IN RARE-EARTH

PARAMAGNETICS IN ULTRA-HIGH MAGNETIC FIELDS UP TO 500 T

V. V. PLATONOV, O. M. TATSENKO, I. M. MARKEVTSEV, M. P. MONAKHOV,

Z. A. KAZEI, R. Z. LEVITIN, N. P. KOLMAKOVA, and A. A. SIDORENKO 
BAND CALCULATION STUDY OF METAMAGNETIC

TRANSITIONS OF FESI IN MEGAGAUSS FIELD

H. OHTA, T. ARIOKA, E. KULATOV, S. HALILOV, and L. VINOKUROVA

USING AN MC-1 FLUX COMPRESSION GENERATOR

L. VEESER, C. EKDAHL, H. OONA, P. RODRIGUEZ, G. SCHMITT, J. SOLEM,

S. YOUNGER, S. BAKER, C. HUDSON, W. LEWIS, B. MARSHALL, W. TURLEY,

A. BYKOV, G. BORISKOV, M. DOLOTENKO, N. EGOROV, N. KOLOKOL'CHIKOV,

M. KOZLOV, Y. KUROPATKIN, and A. VOLKOV

HIGH SENSITIVITY MEGAGAUSS SPECTROSCOPY

N. PUHLMANN, I. STOLPE, H.-U. MÜLLER, O. PORTUGALL, and $M$. VON ORTENBERG

EIGENSTATES OF BLOCH ELECTRONS IN A HIGH MAGNETIC FIELD: OPTICAL PROPERTIES

V. YA. DEMIKHOVSKII, A. A. PEROV, and D. V. KHOMITSKY

CYCLOTRON RESONANCE MEASUREMENT OF BEDT-TTF

SALT UNDER HIGH MAGNETIC FIELD

H. OHTA, Y. OSHIMA, K. AKIOKA, S. OKUBO, and K. KANODA

MAGNETO-RESISTANCE OF $\mathrm{La}_{0,67} \mathrm{Ca}_{0,33} \mathrm{MnO}_{3}$ FILMS IN PULSED HIGH MAGNETIC FIELDS

S. BALEVIČIUS, B. VENGALIS, F. ANISIMOVAS, J. NOVICKIJ, R. TOLUTIS,

O. KIPRIJANOVIČ, J. NOVICKIJ, and L. ALTGILBERS

MAGNETIZATION OF AN $S=1 / 2$ AND 1 FERRIMAGNETIC

CHAIN NiCu(pba) $\left(\mathrm{D}_{2} \mathrm{O}\right)_{3} 2 \mathrm{D}_{2} \mathrm{O}$ IN HIGH MAGNETIC FIELDS

M. HAGIWARA, Y. NARUMI, K. TATANI, K. KINDO, and K. MINAMI

MAGNETIZATION AND MAGNETORESISTANCE MEASUREMENTS

UP TO 60 T AT $70 \mathrm{mK}$

Y. NARUMI, N. TAKAMOTO, K. KINDO, T. C. KOBAYASHI, N. SHIMIZU,

F. IGA, S. HIURA, T. TAKABATAKE, and M. VERDAGUER

MAGNETIZATION CURVES AND MAGNETIC PHASE TRANSITIONS

OF NEW ISING FERRIMAGNETS

A. S. LAGUTIN, G. E. FEDOROV, J. VANACKEN, and F. HERLACH

HIGH FIELD MAGNETIZATION PROCESSES OF $S=1$

ANTIFERROMAGNETIC CHAINS WITH BOND ALTERNATION

M. HAGIWARA, Y. NARUMI, K. KINDO, R. SATO, H. NAKANO, M. KOHNO, and $M$. TAKAHASHI

COMPRESSION OF METALS UNDER INTENSE SHOCK WAVES R. F. TRUNIN

PLASMAS, MAGNETIZED PLASMAS, FUSION

FUSION IN MAGNETICALLY COMPRESSED TARGETS V. N. MOKHOV

MAGNETIZED TARGET FUSION (MTF): A LOW-COST FUSION DEVELOPMENT PATH

I. R. LINDEMUTH, R. E. SIEMON, R. C. KIRKPATRICK, and R. E. REINOVSKY

INITIAL EXPERIMENTS WITH THE PLASMA CHAMBERS MAGO, HAVING NO CENTRAL CURRENT-CARRYING POST IN THE PLASMA HEATING COMPARTMENT

A. A. BAZANOV, and N. I. POZDOV

NUMERICAL SIMULATION OF MAGO/MTF CHAMBER OPERATION AND COMPARISON OF COMPUTED DATA WITH SOME EXPERIMENTS

A. A. BAZANOV, S. F. GARANIN, S. D. KUZNETSOV, V. I. MAMYSHEV,

V. N. MOKHOV, A. N. SUBBOTIN, and V. B. YAKUBOV 
THE ROLE OF DRIFTS IN MAGNETIZED PLASMA OF THE MAGO SYSTEM

S. F. GARANIN

CHARACTERIZATION OF A TARGET PLASMA FOR MTF

F. J. WYSOCKI, J. M. TACCETTI, G. IDZOREK, H. OONA,

R. C. KIRKPATRICK, I. R. LINDEMUTH, P. T. SHEEHEY, and Y. C. F. THIO

MODELING OF PRESENT AND PROPOSED MAGNETIZED

TARGET FUSION EXPERIMENTS

P. SHEEHEY, R. FAEHL, R. KIRKPATRICK, and I. LINDEMUTH

MEASUREMENTS OF DENSE PLASMA PARAMETERS BY

THE INTERACTION OF PLASMA WITH STRONG

MAGNETIC FIELD

V. B. MINTSEV, S. V. DUDIN, V. K. GRYAZNOV, A. E. USHNURTSEV,

N. S. SHILKIN, and V. E. FORTOV

THE STABILITY OF QUASI-ADIABATIC PLASMA COMPRESSION

BY A LONGITUDINAL MAGNETIC FIELD

V. F. YERMOLOVICH, A. I. IVANOVSKY, V. I. KARELIN, A. P. ORLOV, and V. D. SELEMIR

PERPENDICULAR SHOCK WAVE STRUCTURE IN COLD COLLISIONLESS PLASMA CONSISTING OF TWO ION SPECIES

O. M. BURENKOV, and S. F. GARANIN

PLASMA HEATING AND EXPANSION IN ELECTRICAL

EXPLOSION OF A CONDUCTOR IN STRONG MAGNETIC

FIELD

Y. E. ADAMIAN, V. M. VASILEVSKIY, S. N. KOLGATIN, and G. A. SHNEERSON

INTERACTION OF BOUNDARY MATERIAL WITH MAGNETIZED

PLASMA

J. H. DEGNAN, G. F. KIUTTU, B. B. KREH, R. E. PETERKIN, JR,

N. F. RODERICK, E. L. RUDEN, K. F. STEPHENS II, P. J. TURCHI, S. K. COFFEY, M. H. FRESE, D. G. GALE, J. D. GRAHAM, D. MORGAN and D. PLATTS

IMPLODING LINERS FOR CONTROLLED FUSION:

SOME LESSONS LEARNED

P. J. TURCHI

RAILGUNS, LAUNCHERS, AND RELATED TOPICS

HYPERVELOCITY RAILGUN: THE OPTIMAL SOLUTIONS

$V$. E. OSTASHEV, E. F. LEBEDEV, and V. E. FORTOV

CRYOGENIC LAUNCHER EXPERIMENTS: THE QUEST FOR

A VERY HIGH EFFICIENCY

B. M. NOVAC, M. C. ENACHE, P. SENIOR, I. R. SMITH, and K. GREGORY

A. V. BABKIN, S. V. FEDOROV, S. V. LADOV, V. A. GRIGORYAN,

V. A. KRUZHKOV, and A.V. SHERBAKOV

BEHAVIOR OF METALLIC SHAPED-CHARGE JETS

UNDER THE ACTION OF A CURRENT PULSE

G. A. SHVETSOV, A. D. MATROSOV, A. V. BABKIN, S. V. LADOV, and S. V. FEDOROV

FEATURES OF METAL SHAPED CHARGE JET DEFORMATION IN LONGITUDINAL LOW-FREQUENCY MAGNETIC FIELD 
ANALYSIS OF THE DISK EXPLOSIVE MAGNETIC GENERATOR OPERATION IN THE HEL-1 EXPERIMENT

V. K. CHERNYSHEV, V. N. MOKHOV, V. N. BUSIN, O. M. BURENKOV,

A. M. BUYKO, V. V. VAKHRUSHEV, B. E. GRINEVICH, YU. I. GORBACHEV,

A. I. KUZAEV, A. I. KUCHEROV, V. I. MAMYSHEV, YU. I. MATSEV,

A. A. PETRUKHIN, A. I. PISCHUROV, A. I. STARTSEV, V. B. YAKUBOV,

A. G. ANDERSON, C. A. EKDAHL, D. CLARK, I. R. LINDEMUTH,

R. E. REINOVSKY, R. FAEHL, and S. M. YOUNGER

1.3 MV VOLTAGE PULSE FORMATION ON 13 OHM RESISTOR WITH MCG-160

A. S. KRAVCHENKO, A. S. BORISKIN, YU. V. VILKOV, V. D. SELEMIR, YE. M. DIMANT, A. S. YURYZHEV, D. I. ZENKOV, A. A. TKACHUK, YE. N. KIRSHANOVA, M. B. KOZLOV, and T. BOUET

TRANSFORMER EXPLOSIVE MAGNETIC GENERATOR A. JA. KARTELEV and V. K. CHERNYSHEV

HIGH-VOLTAGE POWER SOURCE ON THE BASIS OF MAGNETOCUMULATIVE GENERATOR OF THE TYPE EMG-80

A. S. BORISKIN, YE. M. DIMANT, V. D. SELEMIR, and A. A. SOLOV'YEV

AUTONOMOUS MAGNETOEXPLOSIVE GENERATOR OF MEGAVOLT, 100 NS PULSES

V. YE. GURIN, V. N. KATAEV, P. V. KOROLEV, V. I. KARGIN,

G. F. MAKARTSEV, V. N. NUDIKOV, A. S. PIKAR, N. F. POPKOV, and A. F. SARATOV

HIGH VOLTAGE PULSED MCG-BASED ENERGY SOURCE

E. V. CHERNYKH, V. E. FORTOV, K. V. GORBACHEV, E. V. NESTEROV, S. A. ROSCHUPKIN, and V. A. STROGANOV

THE OUTPUT CHARACTERISTICS OF A TWO-STAGED EXPLOSIVE MAGNETIC COMPRESSION GENERATOR WITH HIGH INDUCTIVE LOAD

X. G. GONG, C. W. SUN, W. P. XIE, Q. Z. SUN, and Z. F. LIU

ON THE DEVELOPMENT OF MCG WITH ARMATURE, ASSEMBLED FROM SEPARATE TUBES

L. N. PLYASHKEVICH

TWO-STAGED MAGNETOCUMULATIVE GENERATORS FOR HIGH IMPEDANCE LOADS

A. E. USHNURTSEV, S. V. DUDIN, V. B. MINTSEV, V. E. FORTOV,

V. E. OSTASHEV, A. A. ULYANOV, E. F. LEBEDEV, A. A. LEONTYEV, and A.V. SHURUPOV

CLASSIFICATION OF HELICAL FLUX-COMPRESSION GENERATORS

B. M. NOVAC and I. R. SMITH

AUTONOMOUS ENERGY SOURCE ON THE BASIS OF HELICAL MCG WITH SIMULTANEOUS HE-CHARGE INITIATION ON THE AXIS

A. S. KRAVCHENKO, YU. V. VILKOV, A. S. YURYZHEV, M. M. SAITKULOV, and I. M. BRUSNIGIN

EXPERIMENTAL INVESTIGATION OF OPERATION OF HELICAL GENERATOR WITH TRANSFORMER ENERGY OUTPUT

A. S. KRAVCHENKO, A. S. BORISKIN, YU. V. VILKOV, YE. M. DIMANT,

A. I. KARPOV, S. T. NAZARENKO, V. S. PAVLOV, and M. B. KOZLOV 
COMPACT HELICAL MAGNETOCUMULATIVE GENERATOR

FOR THE FORMATION OF POWERFUL HIGH-VOLTAGE

ENERGY PULSES

A. S. KRAVCHENKO, V. D. SELEMIR, A. S. BORISKIN, YU. V. VILKOV, YE. M. DIMANT, and A. B. YERMAKOV

ONE APPROACH TO SELECTING THE MAIN PARAMETERS

OF THE EMG HELICAL COIL

V. K. CHERNYSHEV and B. T. YEGORYCHEV

HELICAL EMG EFFECTIVE RESISTANCE

V. K. CHERNYSHEV, E. I. ZHARINOV, V. N. BUSIN, B. E. GRINEVICH,

O. V. SOKOLOVA, G. N. SMIRNOVA, and K. N. KLIMUSHKIN

INVESTIGATION OF MAGNETO-PLASMA COMPRESSOR

OPERATION POWERED FROM A HELICAL FLUX

COMPRESSION GENERATOR

S. N. GOLOSOV, YU. V. VLASOV, V. A. DEMIDOV, and S. A. KAZAKOV

HELICAL EXPLOSIVE FLUX COMPRESSION GENERATOR

RESEARCH AT THE AIR FORCE RESEARCH LABORATORY

422

M. LEHR, D. CHAMA, J. DEGNAN, G. KIUTTU, T. CAVAZOS, D. GALE,

P. PELLITIER, W. SOMMARS, S. COFFEY, L. BAMERT, and K. BELL

SIMULATION, DESIGN AND CONSTRUCTION OF A PULSED

POWER SUPPLY FOR HIGH POWER MICROWAVES USING

EXPLOSIVELY DRIVEN MAGNETIC FLUX COMPRESSION

M. KRISTIANSEN, J. DICKENS, M. GIESSELMANN, E. KRISTIANSEN, and T. HURTIG

GENERATING MICROWAVE RADIATION PULSES WITH MCG

A. G. ZHERLITSYN, G. G. KANAEV, G. V. MELNIKOV,

V. TSVETKOV, A. E. USHNURTSEV, S. V. DUDIN, V. B. MINTSEV, and $V$. E. FORTOV

CONSIDERATIONS OF AN AUTONOMOUS COMPACT SOURCE FOR HIGH POWER MICROWAVE APPLICATIONS

B. M. NOVAC and I. R. SMITH

COMPACT EXPLOSIVE DRIVEN SOURCES OF MICROWAVES:

TEST RESULTS

L. ALTGILBERS, I. MERRITT, M. BROWN, J. HENDERSON,

D. HOLDER, A. VERMA, M. J. HOEBERLING, R. F. HOEBERLING,

G. CARP, W. FENNER, C. M. FOWLER, J. PINA, and M. LEWIS

EXPLOSIVE DEVICE FOR GENERATION OF PULSED FLUXES

OF SOFT X-RAY RADIATION

V. D. SELEMIR, V. A. DEMIDOV, A. V. NANOVSKY,

V. F. YERMOLOVICH, V. G. KORNILOV, V. I. CHELPANOV,

S. A. KAZAKOV, Y. V. VLASOV, and A. P. ORLOV

SHOCK COMPRESSION OF MAGNETIC FIELDS IN CSI

P. TRACY, L. L. ALTGILBERS, I. MERRITT, and M. BROWN

EXPLOSIVE MHD GENERATORS

E. F. LEBEDEV, V. E. OSTASHEV and V. E. FORTOV

OPTIMIZING THE RANCHERO COAXIAL FLUX COMPRESSION GENERATOR

D. G. TASKER, J. H. GOFORTH, W. L. ATCHISON,

C. M. FOWLER, D. H. HERRERA, J. C. KING, I. R. LINDEMUTH, E. A. LOPEZ,

E. C. MARTINEZ, H. OONA, R. E. REINOVSKY,

J. STOKES, L. J. TABAKA, D. T. TORRES, and P. J. MILLER

ENERGY CONVERSION EFFICIENCY OF MCG-BASED

LIGHTNING SIMULATORS

E. V. CHERNYKH, V. E. FORTOV, K. V. GORBACHEV,

I. P. KUJEKIN, E. V. NESTEROV, V. A. STROGANOV,

YU. A. KARPOUSHIN, and A. V. SHOURUPOV 
STABILITY OF MAGNETICALLY IMPLODED LINERS FOR HIGH ENERGY DENSITY EXPERIMENTS

R. REINOVSKY, W. ANDERSON, W. ATCHISON, R. BARTSCH,

D. CLARK, C. EKDAHL, R. FAEHL, J. GOFORTH, R. KEINIGS,

I. LINDEMUTH, D. MORGAN, G. RODRIGUEZ, J. SHLACHTER, and D. TASKER

INSTABILITY GROWTH OF MAGNETICALLY IMPLODED

CYLINDRICAL ALUMINUM AND HIGH-STRENGTH

ALUMINUM ALLOY LINERS

A. M. BUYKO, O. M. BURENKOV, S. F. GARANIN, YU. N. GORBACHEV,

B. E. GRINEVICH, V. V. ZMUSHKO, G. G. IVANOVA, A. I. KUZYAYEV,

V. N. MOKHOV, P. N. NIZOVTSEV, A. A. PETRUKHIN, A. I. PISHCHUROV,

V. P. SOLOVYEV, V. N. SOFRONOV, V. K. CHERNYSHEV, V. B. YAKUBOV.

B. G. ANDERSON, W. E. ANDERSON, W. L. ATCHISON, R. R. BARTSCH,

W. BROSTIE, J. COCHRANE, C. A. EKDAHL, R. FAEHL, I. R. LINDEMUTH,

D. V. MORGAN, H. OONA, R. E. REINOVSKY, J. STOKES, L. C. TABAKA, and S. M. YOUNGER

STUDIES OF SOLID LINER INSTABILITY DURING MAGNETIC IMPLOSION

W. ATCHISON, R. FAEHL, and R. REINOVSKY

HYDRODYNAMIC LINER EXPERIMENTS USING THE

RANCHERO FLUX COMPRESSION GENERATOR SYSTEM

J. H. GOFORTH, W. L. ATCHISON, C. M. FOWLER, D. H. HERRERA,

J. C. KING, E. A. LOPEZ, H. OONA, R. E. REINOVSKY,

J. L. STOKES, L. J. TABAKA, D. G. TASKER, D. T. TORRES,

F. C. SENA, J. A. MCGUIRE, I. R. LINDEMUTH, R. J. FAEHL,

R. K. KEINIGS, O. F. GARCIA, and B. BROSTE

LINER STABILITY EXPERIMENTS AT PEGASUS: DIAGNOSTICS AND EXPERIMENTAL RESULTS

D. A. CLARK, D. V. MORGAN, and G. RODRIGUEZ

IMPLODING LINER MATERIAL STRENGTH MEASUREMENTS

AT HIGH-STRAIN AND HIGH-STRAIN RATE

482

R. BARTSCH, H. LEE, D. HOLTKAMP, B. WRIGHT, J. STOKES,

D. MORGAN, W. ANDERSON, and W. BROSTE

$Z$ AND $\theta$-CURRENT GEOMETRY FEATURES OF METALLIC

TUBES COMPRESSION IN PULSED HIGH MAGNETIC

FIELDS TO STUDY CONSTITUTIVE RELATIONS AT HIGH

STRAIN RATE

Y. A. ALEXEEV, M. N. KAZEEV, and J. PETIT

497

MAGNETIC IMPLOSION FOR NOVEL STRENGTH

MEASUREMENTS AT HIGH STRAIN RATES

H. LEE, D. L. PRESTON, R. R. BARTSCH, R. L. BOWERS,

D. HOLTKAMP, and B. L. WRIGHT

AN EVALUATION OF THE LOS ALAMOS PRECISION AUTOMATED

TURNING SYSTEM (PATS) AS A PRODUCTION TOOL FOR

ATLAS LINERS

W. ANDERSON, R. DAY, D. HATCH, R. GORE, D. MACHEN,

J. BARTOS, M. SALAZAR, and P. HANNAH

FABRICATION PROCESS FOR MACHINED AND SHRINK-FITTED

IMPACTOR-TYPE LINERS FOR THE LOS ALAMOS

HEDP PROGRAM

B. RANDOLPH

FABRICATION OF HIGH ENERGY DENSITY PHYSICS LOADS

M. A. SALAZAR, W. ANDERSON, E. ARMIJO, and F. GARCIA 
CAGEN: A MODERN, PC BASED COMPUTER MODELING TOOL FOR EXPLOSIVE MCG GENERATORS AND ATTACHED LOADS

J. B. CHASE, D. CHATO, G. PETERSON, P. PINCOSY, and G. F. KIUTTU

AN INTEGRATED SOFTWARE PACKAGE FOR THE DESIGN OF HIGH PERFORMANCE PULSED MAGNETS

J. VANACKEN, LI LIANG, L. TRAPPENIERS, K. ROSSEEL, W. BOON, and F. HERLACH

NUMERICAL SIMULATION OF OPERATION OF MAGNETOCUMULATIVE GENERATORS WITH HIGH ENERGY GAIN

A. S. KRAVCHENKO and YU. V. VILKOV

A FIELD-THEORY APPROACH TO MODELING HELICAL FCGS C. M. FORTGANG

NUMERICAL SIMULATION OF MAGNETIC FLUX COMPRESSION IN HELICAL-CONE MAGNETOEXPLOSIVE GENERATORS YU. N. DERYUGIN, P. V. KOROLEV, V. I. KARGIN, A. S. PIKAR, N. F. POPKOV, and E. A. RYASLOV

SEMI-EMPIRICAL MODEL FOR THE RESISTANCE OF SPIRAL MAGNETOCUMULATIVE GENERATORS L. ALTGILBERS, I. MERRITT, M. BROWN, and P. TRACY

VOLTAGE DISTRIBUTION OVER EMG HELIX WIRES V. R. CHERNYSHEV, E. I. ZHARINOV, V. N. BUZIN, B. E. GRINEVICH, K. N. KLIMUSHKIN, I. D. KUDELKIN, A. A. BAZANOV, O. V. SOKOLOVA, M. M. GUBIN, S. V. PAK, and A. N. SKOBELEV

CALCULATION OF THE AUTONOMOUS MC-GENERATOR WITH A PERMANENT MAGNET

V. E. GURIN, V. I. KARGIN, A. S. PIKAR, N. F. POPKOV, and E. A. RYASLOV

2-D HYDRODYNAMIC FLOWS CALCULATION AT ISENTROPIC SUBSTANCE COMPRESSION WITH ULTRA-HIGH MAGNETIC FIELD PRESSURE

V. V. ASEEVA, G. V. BORISKOV, and A. I. PANOV

EXPLOSIVE AXIAL MAGNETIC FLUX COMPRESSION GENERATOR ARMATURE MATERIAL STRENGTH AND COMPRESSION EFFECTS

E. L. RUDEN, G. F. KIUTTU, R. E. PETERKIN, JR, and J. B. CHASE

ON FEASIBILITY OF RAYLEIGH-TAYLOR INSTABILITY MAGNETIC STABILIZATION OF LINER IMPLOSIONS

S. F. GARANIN, S. D. KUZNETSOV, V. N. MOKHOV, L. V. YAKUBOVA, V. B. YAKUBOV, and C. EKDAHL

2-D INSTABILITY SIMULATION OF MAGNETICALLY DRIVEN CYLINDRICAL ALUMINUM AND ALUMINUM ALLOY LINERS

A. M. BUYKO, S. F. GARANIN, V. V. ZMUSHKO, V. N. MOKHOV, P. N. NIZOVTSEV, V. P. SOLOVYEV, and V. B. YAKUBOV

EXPLORING WAYS TO IMPROVE Z-PINCH CALCULATIONS

W. MATUSKA, J. AUBREY, R. BOWERS, H. LEE, D. PETERSON, C. DEENEY, M. DERZON, and T. NASH

THE APPLICATION OF 2-D SIMULATIONS TO Z-PINCH EXPERIMENT DESIGN AND ANALYSIS

D. L. PETERSON, R. L. BOWERS, W. MATUSKA, G. A. CHANDLER,

C. DEENEY, M. S. DERZON, M. K. MATZEN, R. C. MOCK,

T. J. NASH, T. W. L. SANFORD, R. B. SPIELMAN, and K. W. STRUVE 
PLASMADYNAMIC SWITCHING AT MEGAGAUSS MAGNETIC

FIELD LEVELS

P. J. TURCHI

MACH2 SIMULATIONS OF THE DECADE PLASMA OPENING

SWITCH USING A TEFLON PLASMA

589

D. KEEFER and R. RHODES

SHOCK-WAVE DRIVEN FLUX COMPRESSION TECHNIQUE

E. I. BICHENKOV

ELECTRICAL CONDUCTIVITY OF THE DETONATION PRODUCTS

593

P. I. ZUBKOV

ANALYSIS OF THE SPATIAL VARIATION AND TIME DEPENDENCE

OF THE CURRENT DISTRIBUTION IN A SINGLE-TURN

COIL FOR MEGAGAUSS FIELDS

604

H.-U. MUELLER, O. PORTUGALL, and M. VON ORTENBERG

SWITCHES AND OTHER

609

CURRENT PULSE SHARPENING BY FERROMAGNETIC

OPENING SWITCH

G. A. SHNEERSON, I. P. EFIMOV, S. I. KRIVOSHEEV, and YU. N. BOTCHAROV

OPENING MECHANISMS IN AN EXPLOSIVELY FORMED

FUSE OPENING SWITCH

D. KEEFER, M. H. FRESE, L, D. MERKLE, R. E. PETERKIN, JR., N. F. RODERICK, and K. F. STEPHENS $\|$

HIGH VOLTAGE APPLICATIONS OF EXPLOSIVELY FORMED FUSES

D. G. TASKER, J. H. GOFORTH, C. M. FOWLER, D. H. HERRERA,

J. C. KING, E. A. LOPEZ, E. C. MARTINEZ, H. OONA, S. P. MARSH,

R. E. REINOVSKY, J. STOKES, L. J. TABAKA, D. T. TORRES,

F. C. SENA, G. KIUTTU, and J. DEGNAN

HIGH EFFICIENCY CLOSING SWITCHES FOR MEGAMP

PULSED CURRENTS

P. SENIOR and I. SMITH

FIRST RESULTS OF MULTI-RADIOGRAPHY IN THE EXPERIMENTS WITH MC-1 GENERATOR

G. V. BORISKOV, A. I. BYKOV, M. I. DOLOTENKO, N. I. YEGOROV,

N. P. KOLOKOL'CHIKOV, YU. P. KUROPATKIN, N. B. LUKYANOV,

V. D. MIRONENKO, V. N. PAVLOV, and V. I. TIMAREVA

EXPERIMENTAL INSTALLATION FOR ELECTRODYNAMIC

COMPRESSION

B. E. FRIDMAN, N. N. KUSTOV, A. G. LEX, and PH. G. RUTBERG

GENERATION OF HIGH-POWER SHOCK WAVES ON

PIRIT-2 FACILITY

M. V. ZHERNOKLETOV, V. I. KARGIN, D. V. KOTELNIKOV,

A. V. MELKOZEROV, A. L. MIKHAILOV, A. Y. NAGOVITSIN,

N. F. POPKOV, and E. A. RYASLOV

STEEL AND GRAPHITE HEATING BY MEGAAMPERE

CURRENT PULSES

B. E. FRIDMAN, A. G. LEX, I. P. MAKAREVICH, PH. G. RUTBERG, and A. D. RAKHEL

A HIGH-VOLTAGE PULSE TRANSFORMER FOR EXPLOSIVE PULSED-POWER DEVICES

C. FORTGANG, A. ERICKSON, and J. GOETIEE 
$1 \mathrm{MV}, 20 \mathrm{NS}$ PULSE GENERATOR FOR HIGH-CURRENT MAGNETRON

V. I. KARGIN, A. S. PIKAR, N. F. POPKOV, E. A. RYASLOV,

E. B. ABUBAKIROV, N. F. KOVALEV, and M. I. FUCHS

\section{HIGH MAGNETIC FIELD FACILITIES}

Z: A FAST PULSED POWER GENERATOR FOR ULTRA-HIGH MAGNETIC FIELD GENERATION

R. B. SPIELMAN, W. A. STYGAR, K. W. STRUVE, J. R. ASAY,

C. A. HALL, M. A. BERNARD, J. E. BAILEY, and D. H. MCDANIEL

GENERATION OF MEGAGAUSS FIELDS BY ELCTROMAGNETIC

FLUX COMPRESSION AND THE SINGLE-TURN COIL

TECHNIQUE AT ISSP

N. MIURA, Y. H. MATSUDA, K. UCHIDA, and S. TODO

THE ATLAS PULSED POWER SYSTEM; A DRIVER FOR

PRODUCING MULTI-MEGAGAUSS FIELDS

J. C. COCHRANE, JR, R. R. BARTSCH, G. A. BENNETT,

D. W. BOWMAN, H. A. DAVIS, C. A. EKDAHL, R. F. GRIBBLE,

H. J. KIMERLY, K. E. NIELSEN, W. M. PARSONS, J. D. PAUL,

D. W. SCUDDER, R. J. TRAINOR, M. C. THOMPSON,

and R. G. WATT

MULTI-MODULE FLUX COMPRESSION ENERGY

SOURCE "SPRUT"

V. A. DEMIDOV, V. D. SELEMIR, S. A. KAZAKOV, YU. V. VLASOV,

R. M. GARIPOV, and A. P. ROMANOV

CONVENTIONAL AND EXPLOSIVE PULSED POWER

DEVELOPMENT AT TEXAS A\&M UNIVERSITY

B. FREEMAN, T. FALESKI, I. HAMILTON, J. ROCK, and T. PARISH

THE HUMBOLDT HIGH MAGNETIC FIELD CENTER:

MEGAGAUSS OPERATION AND RESULTS UP TO 300 TESLA

M. VON ORTENBERG, O. PORTUGALL, N. PUHLMANN,

H.-U. MUELLER, I. STOLPE, and A. KIRSTE

THE EUROPEAN $100 \mathrm{~T}$ PROTOTYPE PROJECT

P. P. J. VAN ENGELEN and W. JOSS

HIGH FIELD LABORATORY DRESDEN

R. KRATZ

THE TOULOUSE $14 \mathrm{MJ}$ CAPACITOR BANK PULSE GENERATOR

S. ASKENAZY, L. BENDICHOU, G. COFFE, P. FERRE,

J. M. LAGARRIGUE, J. P. LAURENT, F. LECOUTURIER, J. MARQUEZ,

S. MARQUEZ, and D. RICART

GENERATION OF HIGH MAGNETIC FIELDS IN THE MEGAGAUSS RANGE AT THE OSAKA FACILITY

K. KINDO

680

THE NEW OXFORD HIGH FIELD FACILITY

H. JONES

AUTHOR INDEX 